\title{
Mechanisms of oral tolerance to insulin in offspring of rats with experimental gestational diabetes
}

\author{
Tanya Prozorova ${ }^{1 *}$, Alex Kamyshny ${ }^{2}$, Vita Kamyshna ${ }^{3}$ \\ ${ }^{1}$ Department of Normal Physiology, Zaporozhye State Medical University, Ukraine. \\ ${ }^{2}$ Department of Microbiology, Virology and Immunology, Zaporozhye State Medical University, Ukraine. \\ ${ }^{3}$ Department of Normal Anatomy, Zaporozhye State Medical University, Ukraine.
}

\begin{abstract}
Background: The aim of our work was to find out the mRNA gene expression level of Aire, Deaf1, Foxp3, Ctla4 and IL10 in mesenteric lymph nodes in the offspring of rats with experimental gestational diabetes and in conditions of insulin oral tolerance formation.

Material and Methods: Using molecular genetic and immunofluorescence techniques we investigated the mRNA gene expression level of Aire, Deaf1, Foxp3, Ctla4 and IL10 in the offspring of rats with experimental gestational diabetes and in conditions of insulin oral tolerance formation. To determine the level of mRNA studied gene RT-PCR was performed in real time thermocycler CFX96 ${ }^{\mathrm{TM}}$ Real-Time PCR Detection Systems.

Results: We observed such violations of immunotolerance: AIRE gene repression, reduced mRNA levels of Deaf1 and the transcription factor Foxp3. This was accompanied by inhibition of gene expression suppressor cytokine IL-10 and negative costimulatory molecules Ctla4.

Conclusion: Oral insulin during the first 2 weeks graded these changes, causing transcriptional activation of genes AIRE, Deaf1, Foxp3, Ctla4 and Il-10.
\end{abstract}

Key words: Experimental gestational diabetes, mesenteric lymph nodes, Aire, Deaf1, Foxp3.

\section{Introduction}

Formation of immunological tolerance to autoantigens is an important mechanism that prevents the development of autoimmune diseases. In recent years there was found extrathymic expression a number of peripheral tissuespecific antigens (PTSAs), including such pancreatic antigens as insulin and proinsulin. Ectopic transcription regulator of them is autoimmune regulator (Aire) (1). A lot of extrathymic Aire-expressing cells (eTACs) are found in lymphatic nodes (LN) and represent one of the critical factors of peripheral immunological tolerance (PIT) (2). Stromal mesenteric lymph node cells that include fibroblast reticular cells, follicular dendritic cells and lymphatic endothelial cells express PTSAs (3), but their expression regulates not only eTACs. They control transcription regulator Deaf1 (deformed autoregulatory factor 1) (4). Consequently Aire and Deaf1 are important differentiation regulators of inducible regulatory $\mathrm{T}$-cells (iTreg), other participant that can proceed negative control of AID developing. iTreg can express transcription factor Foxp3 (5), their action realized through production of suppressor cytokines - IL10, IL13, IL35, TGF $\beta$ (6), perforin/granzyme-dependent cytolysis of effector cells and depends on the expression of negative costimulatory molecules such as CTLA-4 (cytotoxic T-lymphocyte-associated protein 4) (7).
*Corresponding Author: Tanya Prozorova, MD, Human Physiology Department, 69035, Mayakovsky avenue 26, Zaporizhzhya State Medical University, Zaporizhzhya, Ukraine. E-mail: prozorova_t@i.ua Received: Apr 12, 2016. Accepted: Feb 04, 2017
This is an Open Access article distributed under the terms of the Creative Commons Attribution Non-Commercial License (http://creativecommons.org/licenses/bync/4.0/) which permits unrestricted non-commercial use, distribution, and reproduction in any medium, provided the original work is properly cited. 
Thus stromal Deaf1-expressing cells of mesenteric lymph nodes (MLN) produce retinoic acid that promotes Foxp $3^{+}$-regulatory T-cells (8). Yang S. et al. (2015) demonstrated ability of Aire generate in the prenatal period (up to 10 days after birth inclusive) special population of FoxP3 ${ }^{+}$Treg-cells, which remains stable in adults and mice (9).

Consequently intranatal hyperglycemia that develops in gestational diabetes (GD) can influence on the morphogenesis of the immune system and leads to violations of PIT formation to pancreatic antigens. Using mucosa is an attractive way to treatment by administering antigens as tolerogen, especially in young and healthy children. In animal models oral or intranasal administration of antigens can induce PIT, and the main places for PIT induction are mesenteric lymph nodes (MLN), where intensive activation of naïve T-cells and their differentiation into subpopulation of effector cells are happened (10). Therefore, the aim of our work was to find out the mRNA gene expression level of Aire, Deafl, Foxp3, Ctla4 and IL1O in mesenteric lymph nodes in the offspring of rats with experimental gestational diabetes and in conditions of insulin oral tolerance formation.

\section{Material and methods}

The studied animals were divided into 6 experimental groups each contains 20 rats. Descendants of intact Wistar rats (males) 1 month of age (group 1) and 6 months of age (group 2). Their mothers were admistered $0,5 \mathrm{ml} 0,1 \mathrm{M}$ citrate buffer $(\mathrm{pH}=4,5)$ on the 15 th day of pregnancy once intraperitoneally. Descendants of rats Wistar (males) with experimental gestational diabetes (EGD) 1 month of age (group 3) and 6 months (group 4). Their mothes were admistered $45 \mathrm{mg} / \mathrm{kg}$ of streptozotocin once intraperitoneally on the 15th day of pregnancy. Descendants of rats with EGD 1 month of age (group 5) and 6 month of age (group 6) which received short-acting human insulin orally using a pipette for the first 14 days of life (ACTRAPID ${ }^{\circledR}$ HM, NOVO NORDISK, Denmark) at a dose of $30 \mathrm{IU}(1050 \mu \mathrm{g}=1,05$ $\mathrm{mg}, 1 \mathrm{IU}$ corresponds to $35 \mu \mathrm{g}$ of anhydrous human insulin).

As objects for molecular genetic studies using real-time reverse transcription polymerase chain reaction (rt-pcr) techniques were MLN of experimental animals. They were placed in the Bouin's fluid, dehydrated with graded concentrations of ethanol and embedded in paraffin. Molecular genetic studies performed on archival material 2 years old. RNA extracted from histology sections 15 $\mu \mathrm{m}$ thick. They were dewaxed in xylene and rehydrated with descending concentrations of ethanol (100\%, 96\%, $70 \%)$. Total RNA was procured from samples by use of “Trizol RNA Prep 100" (Isogen Lab LTD, Russia), that contains Trizol reagent (lysis reagent, which includes denaturing agent guanidine thiocyanate and phenol with $\mathrm{pH}=4.0$ ) and ExtraGene E (slurry mixture of ionexchangers). RNA isolated according to set protocol.

For reverse transcription and obtaining cDNA we used RT-1 set «Syntol» (Russia). The reaction mixture is a total volume of $25 \mu 1$ and contains $1 \mu 1$ of Random- 6 primer, $2 \mu 1$ total RNA, $8,5 \mu 1$ deionized and cleaned of nucleases $\mathrm{H} 2 \mathrm{O}, 12,5 \mu 12,5 \mathrm{x}$ reaction mixture and $1 \mu 1$ of reverse transcriptase MMLV-RT. Reverse transcription conducted at $45^{\circ} \mathrm{C}$ for $45 \mathrm{~min}$, then $92^{\circ} \mathrm{C}$ for $5 \mathrm{~min}$ for inactivation of MMLV-RT.

To determine the level of mRNA Aire (NM_001106379.1), Deaf1 (NM_031801.1), Foxp3 (NM_001108250.1), IL10 (NM_012854.2) and Ctla4 (NM_031674.1) we used thermocycler CFX96 ${ }^{\text {TM} R e a l-~}$ Time PCR Detection Systems («Bio-Rad Laboratories, Inc.», USA) set of reagents Maxima SYBR Green/ROX qPCR MasterMix (2X) (ThermoScientific, USA). The final reaction mixture for amplification includes coloring SYBR Green, Maxima HotStartTaq DNA Polymerase, $0,2 \mu 1$ of forward and reverse specific primers, $1 \mu 1$ cDNA. The reaction mixture brought to total volume 25 $\mu 1$ by adding deionized $\mathrm{H} 2 \mathrm{O}$. Specific primer pairs ( $\left.5^{\prime}-3^{\prime}\right)$ for analysis of target and reference genes were selected by the software PrimerBlast (www.ncbi.nlm.nih.gov/tools/primer-blast) and produced by Metabion (Germany) (Table.1).

After initial denaturation at $95^{\circ} \mathrm{C}$ for $10 \mathrm{~min}$ amplification consisted of 45 cycles and conducted under the following conditions: denaturation $-95^{\circ} \mathrm{C}$ for $15 \mathrm{sec}$, annealing at $59-61^{\circ} \mathrm{C}$ for $30-60 \mathrm{sec}$, elongation at $72^{\circ} \mathrm{C}$ for $30 \mathrm{sec}$. As reference gene to determine the relative value of changes in the expression level of target genes was used glyceraldehyde 3-phosphate dehydrogenase (GAPDH) gene. Normalized relative quantity of cDNA target genes was determined by the method $\Delta \Delta \mathrm{Ct}$. Statistical data analysis of PCR were conducted using available software CFX Manager TM(Bio-Rad, USA). 
Table 1. Primer list used in the study.

\begin{tabular}{|c|c|c|c|c|}
\hline Gene & Primer & $\mathbf{T m},{ }^{\circ} \mathrm{C}$ & $\begin{array}{l}\text { Product length } \\
\text { (bp) }\end{array}$ & Exon junction \\
\hline Aire & $\begin{array}{l}\mathrm{F}=\text { GCCTAAAGCCAGTGATCCGA } \\
\mathrm{R}=\text { TCTCTACCCTGGGTTCCCTTT }\end{array}$ & $\begin{array}{l}59.82 \\
59.85\end{array}$ & 43 & $\begin{array}{l}850 / \\
851\end{array}$ \\
\hline Deaf1 & $\begin{array}{l}\mathrm{F}=\text { GCAGAGAGGAAGGAGCAGTC } \\
\mathrm{R}=\text { GTGCACTCACTCATGGCCT }\end{array}$ & $\begin{array}{l}59.82 \\
60\end{array}$ & 59 & $\begin{array}{l}1605 / \\
1606\end{array}$ \\
\hline Foxp3 & $\begin{array}{l}\mathrm{F}=\text { CGAGACTTGGAAGTCAGCCAC } \\
\mathrm{R}=\text { TCTGAGGCAGGCTGGATAACG }\end{array}$ & $\begin{array}{l}60.94 \\
61.91\end{array}$ & 61 & $\begin{array}{l}214 / \\
215\end{array}$ \\
\hline ILIO & $\begin{array}{l}\mathrm{F}=\text { AGTGGAGCAGGTGAAGAATGA } \\
\mathrm{R}=\text { GACACCTTTGTCTTGGAGCTTATTA }\end{array}$ & $\begin{array}{l}59.02 \\
59.06\end{array}$ & 49 & $\begin{array}{l}445 / \\
446\end{array}$ \\
\hline Ctla4 & $\begin{array}{l}\mathrm{F}=\text { TACAGTTTCCTGGTCACCGC } \\
\mathrm{R}=\text { AGGACTTCTTTTCTTTAGCGTCCT }\end{array}$ & $\begin{array}{l}59.97 \\
59.96\end{array}$ & 57 & $\begin{array}{l}567 / \\
568\end{array}$ \\
\hline GAPDH & $\begin{array}{l}\mathrm{F}=\text { GCCTGGAGAAACCTGCCAAG } \\
\mathrm{R}=\text { GCCTGCTTCACCACCTTCT }\end{array}$ & $\begin{array}{l}61 \\
60\end{array}$ & 52 & $\begin{array}{l}825 / \\
826\end{array}$ \\
\hline
\end{tabular}

Experiment included negative controls: no template controls (cDNA and mRNA) and no reverse transcriptase control. All amplification reactions were performed on individual samples three times.

\section{Results}

Investigation of Aire gene expression in MLN showed that in the offspring of EHD rats there is a significant reduction of mRNA of autoimmune regulator 8,1 times $(\mathrm{p}<0,05)$ in the 1-month-old rat and 2,3 times $(\mathrm{p}<0,05)$ in the 6-month-old animals compared with control groups (Fig. 1 A, B).

mRNA content of transcription regulator Deaf1 in the 1month-old animals significantly didn't changed, and in the 6-month-old descendants we observed its reduction 9,2 times (p <0,05) (Fig.1 C, D). As for mRNA of transcription factor Foxp3, there was revealed a significant decrease 50 times $(\mathrm{p}<0,05)$ in the 1 -monthold rats of this group, and 2,5 times $(\mathrm{p}<0,05)$ in the 6month-old animals compared with control (Fig.1 E, F).

Groups of the offspring of EHD rats, that were administered oral insulin for a duration of 14 first days of life showed growth of Aire gene transcriptional induction in the 1-month-old rats. Contents of mRNA autoimmune regulator increased 13,2 times ( $\mathrm{p}<0,05)$, in the 6-monthold it grows 2 times ( $<<0,05)$ (Fig.2 A, B). Transcription regulator Deaf1 in first age group showed a significant increase 11,5 times $(\mathrm{p}<0,05)$, and in the next group came back to level of EHD (Fig.2 C, D).
Studies have shown that expression of the transcription factor Foxp3 in the 6-month-old rats was increase of Foxp3 mRNA 5,2 times ( $\mathrm{p}<0,05)$, in the 6-month-old animals rise was 3,3 times ( $\mathrm{p}<0,05$ ) (Fig.2 E, F).

In experimental groups that received oral insulin were also investigated mRNA expression of costimulatory molecules Ctla4 and Treg-dependent suppressor cytokine IL-10. There were obtained such results: the relative quantity of Ctla4 mRNA gene increased 12,2 times (p $<0,05)$ at 1 month of age, at 6 months of age it significantly not changed (Fig.3 A, B). Contents of mRNA IL10, on the contrary, in first age group was unaltered, but in the 6-month-old rats it increased 15 times $(\mathrm{p}<0,05)$ (Fig.3 C, D).

\section{Discussion}

Peripheral immunological tolerance could take place systemically after antigen feeding, there has been no reason to doubt that it takes place largely within the local mucosal immune system. MLN are the main site for oral tolerance (OT) induction between other lymphoid tissues. Presentation of fed antigens occurs preferentially in the MLN, rather than the Peyer's patches (PP) (11). OT cannot be induced in mice lacking MLN, but it is unaffected in mice, that lack PP (12). Furthermore, it has been shown that DCs constitutively traffic from the intestinal epithelium and Peyer's patches to the MLN, so there is a clear mechanism whereby antigen can be picked up at the intestinal epithelial surface and taken to the MLN, where T cell tolerization can occur. (13). 

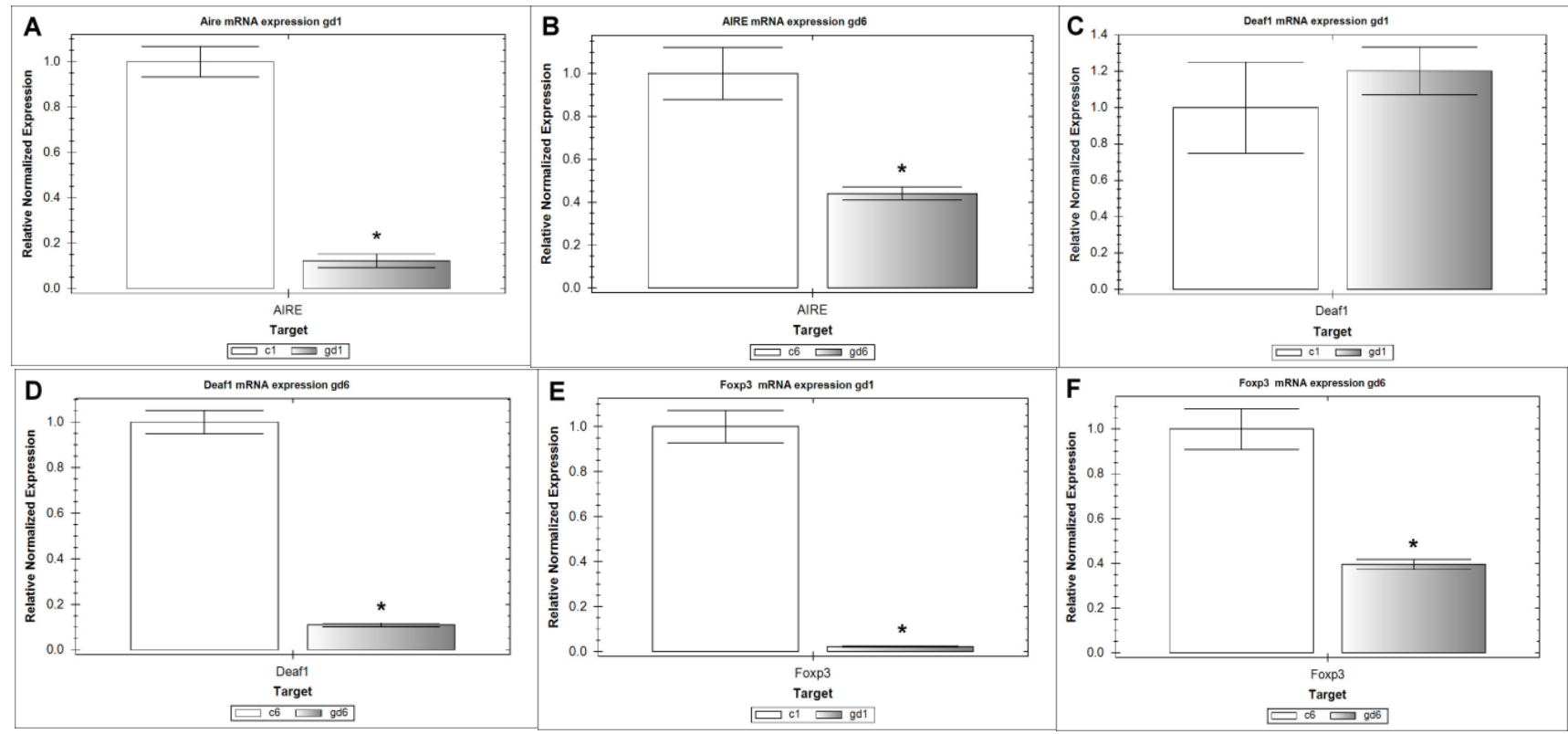

Figure 1. Normalized relative quantity of mRNA Aire (A, B), Deafl (C, D) and Foxp3 (E, F) genes in MLN cells. Normalized to reference gene GAPDH by the method $\Delta \Delta \mathrm{Ct}$. c1, c6 - control 1 and 6 months; gd1, gd6 - offspring of EHD rats.
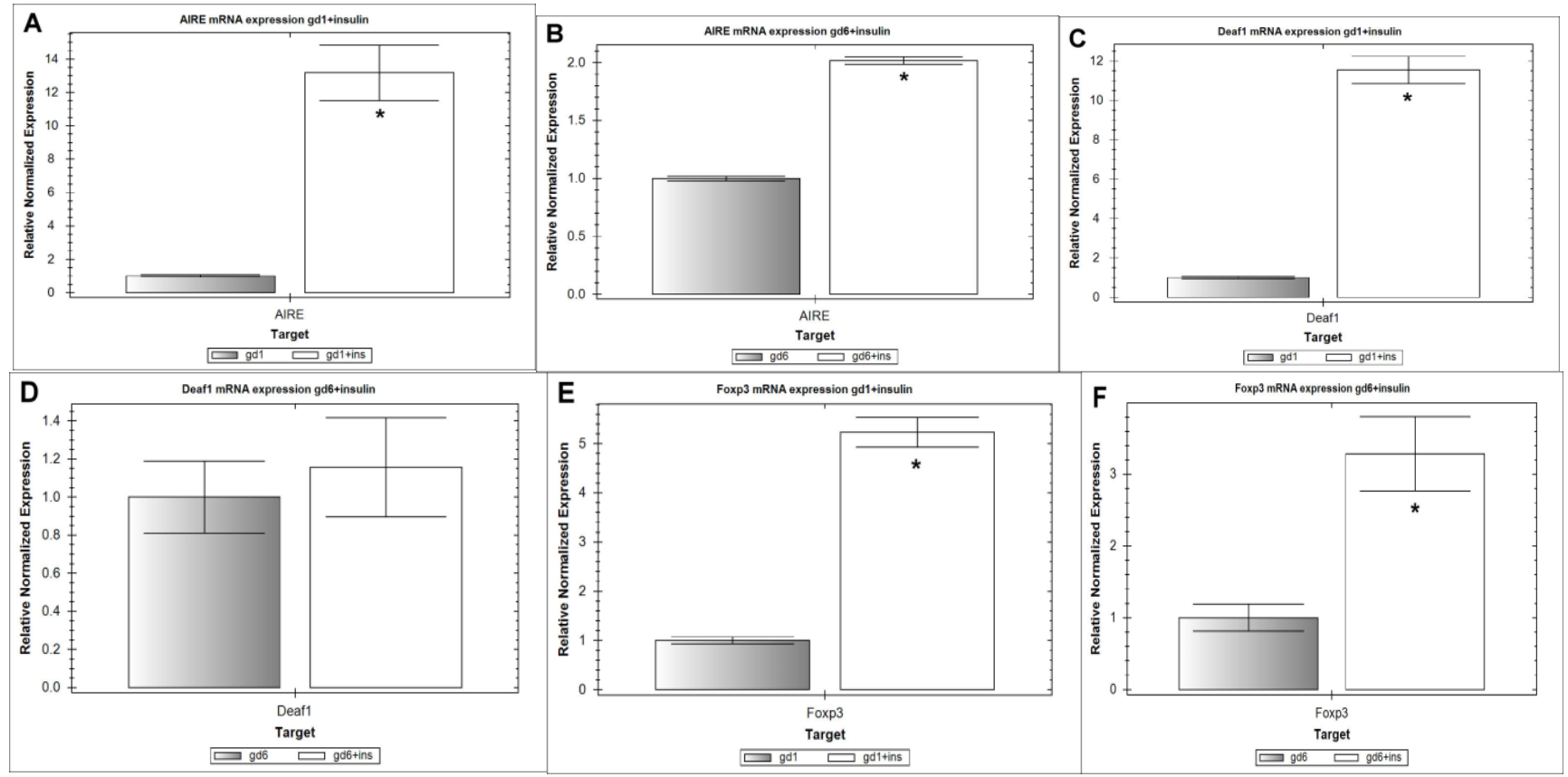

Figure 2. Normalized relative quantity of mRNA Aire (A,B), Deaf1 (C,D) and Foxp3 (E,F) genes in MLN cells. Normalized to reference gene GAPDH by the method $\Delta \Delta \mathrm{Ct}$. gd1, gd6 - offspring of EHD rats; gd1+ins, gd6+ins - after insulin administrations. 


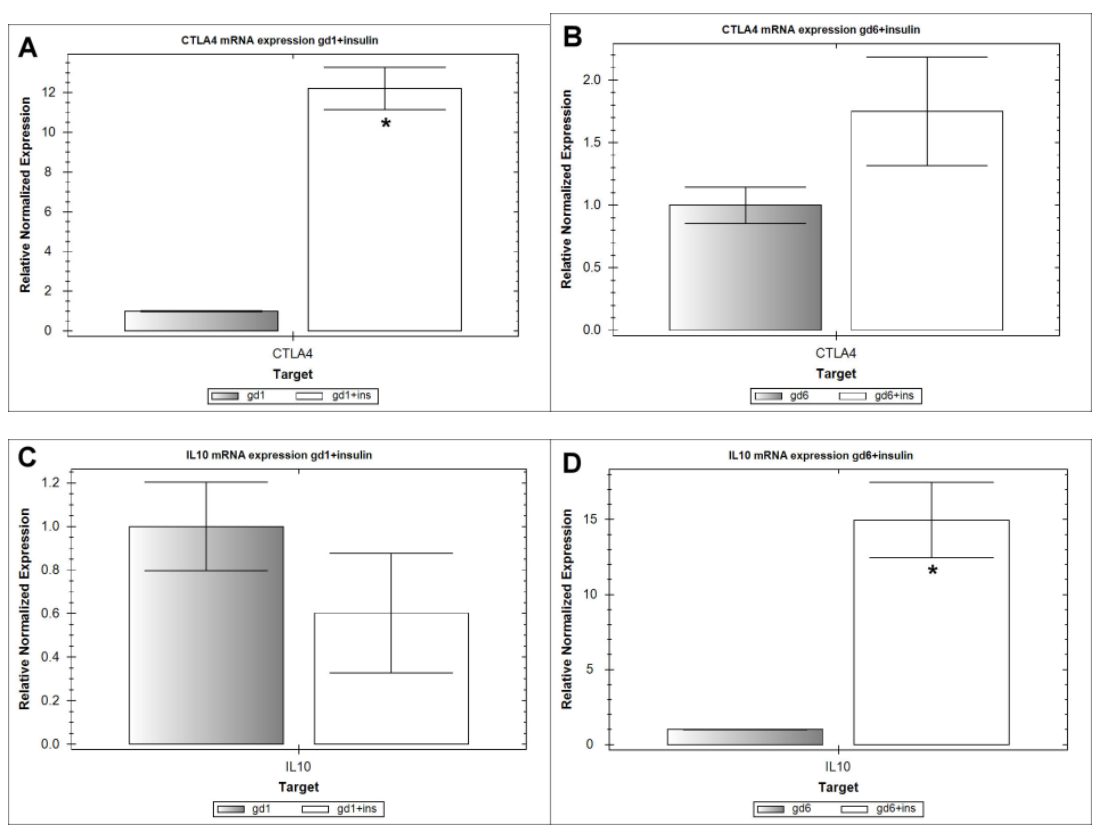

Figure 3. Normalized relative quantity of mRNA Ctla4 (A,B) and IL10 (C,D) genes in MLN cells. Normalized to reference gene GAPDH by the method $\Delta \Delta \mathrm{Ct}$. gd1, gd6 - the offspring of EHD rats; gd1+ins, gd6+ins - after insulin administration.

Worbs et al. (2006) evidently shows that in mice the MLN are an obligatory and exclusive site of oral tolerance induction (14). TCR transgenic T cells were seen to proliferate at day 2 after antigen feeding in the MLN, but not until day 4 in peripheral lymph nodes. Using the drug FTY720 (blocker of lymphocyte migration from LN) or surgical excision of the MLN violated the process. The authors then used two experimental systems to show that antigen-laden DCs migrating from the intestinal wall to the MLN can tolerize MLN-resident T cells. First, in an animal with an intestinal transplant in which the vascular supply is anastomosed to the host, but the lymphatic system is separate, an oral protein challenge caused T cells only in the host and not the graft MLN to be stimulated. Second, in mice deficient for the chemokine receptor CCR7, which have impaired DC migration to MLN. In this group $\mathrm{T}$ cell stimulation and functional oral tolerance were abrogated. These experiments allowed them to conclude that oral tolerance is exclusively generated in the MLN with antigen transported from the intestinal surface by DCs through the afferent lymphatics.
On the other hand, clinical manifestation of T1DM is preceded by the development of autoantibodies to different islet autoantigens, marking the loss of immunological tolerance to $\beta$ cells. Development of T1DM in individuals with multiple islet autoantibodies is almost inevitable, and increases the urgency to intervene in the disease process before hyperglycaemia develops. Most trials attempting immune intervention have been conducted in patients with recent onset T1DM (usually within 6 weeks of diagnosis), and have had varying but only limited success. (15). This outcome might partly result from the stage of disease and progressive loss of $\beta$ cells, in addition to the burden of poor glycaemic control and metabolic $\beta$-cell stress over and above the inflammatory insult. Unfortunately, the few attempts to prevent T1DM using immunotherapy in seropositive individuals at risk of the disease were unsuccessful. (16). Although several explanations for this setback exist including the type of drug or islet autoantigen, dosing and method of administration. Primary prevention before seroconversion might conceivably be an attractive and simple solution, that is why we have chosen this path. The correctness of this approach is confirmed by the preliminary results of the Bonifacio E. et al. (2015) study. 
They performed a double-blind, placebo-controlled, doseescalation, clinical pilot study to assess the immune responses and adverse events associated with orally administered insulin in healthy, autoantibody-negative children, but who were genetically at-risk of developing T1DM (17). This treatment approach proved safe, with no serious adverse events related to treatment. No episode of hypoglycaemia (in spite of daily insulin doses up to $67.5 \mathrm{mg}$ ), allergic reactions or induction of unwanted islet autoimmunity were observed. Instead, moderate changes in immunity to insulin were noted CD4+-T-cell proliferative responses to insulin regulatory type, which was confirmed by transcriptome analysis of clonal CD4 T-cells reactive to insulin or proinsulin and finding Foxp3 (18). Exploiting the mucosa is an attractive choice of treatment to administer antigens as tolerogen, especially in young and healthy children. In animal models, oral or intranasal administration of an antigen can induce specific immune regulation of the tolerogen of choice. (19). Our results also confirmed by the fact that the decrease of Deaf 1 mRNA in conditions of streptozotocin-induced diabetes inhibits Foxp3+regulatory $\mathrm{T}$-cells differentiation in pancreatic lymph nodes of rats (20) .

\section{Conclusion}

There is a transcription repression of Aire gene, decrease level of Deaf1 mRNA in the offspring of rats with EGD that violates ectopic transcription of pancreatic antigens in MLN. Reduction of mRNA Foxp3 level leads to a deficiency of suppressor signaling that also confirmed inhibition of gene expression of supressor cytokine IL10 and negative costimulatory molecules Ctla4.

Oral administration of insulin during the first 2 weeks graded these changes, causing transcription activation of AIRE, Deaf1, Foxp3, Ctla4 and IL10 genes.

Ethics Committee Approval: Ethics Committee approval was received for this study from the ethics committee.

\section{Informed Consent: NA}

Peer-review: Externally peer-reviewed.

Conflict of Interest: No conflict of interest was declared by the author.

Financial Disclosure: The author declared that this study has received no financial support.

\section{References}

1. Metzger T, Anderson M. Control of central and peripheral tolerance by Aire. Immunol Rev 2011; 241: 89-103.

2. Kojima H, Fujimiya M, Matsumura K. Extrapancreatic insulin-producing cells in multiple organs in diabetes. Proc. Natl. Acad. Sci USA 2004; 101: 2458-2463.

3. Cohen J, Tewalt E, Rouhani S. Tolerogenic properties of lymphatic endothelial cells are controlled by the lymph node microenvironment. PLOS ONE 2014; 9:e87740.

4. Yip L, Su L, Sheng D. Deaf1 isoforms control the expression of genes encoding peripheral tissue antigens in the pancreatic lymph nodes during type 1 diabetes. Nat. Immunol. 2009:1026-1033

5. Shevach E, Thornton A. tTregs, pTregs, and iTregs: similarities and differences. Immunol Rev 2014;259:88-102.

6. Wang S, Gao X, Shen G, Wang W, Li J, Zhao J. Interleukin10 deficiency impairs regulatory $\mathrm{T}$ cell-derived neuropilin-1 functions and promotes Th1 and Th17 immunity. Sci Rep 2016;6:24249.

7. Walker LS, Sansom DM. Confusing signals: recent progress in CTLA-4 biology. Trends Immunol 2015;36:63-70.

8. Hammerschmidt SI, Ahrendt M, Bode U, Wahl B, Kremmer E, Förster R, Pabst O. Stromal mesenteric lymph node cells are essential for the generation of gut-homing $\mathrm{T}$ cells in vivo. $J$ Exp Med 2008;205:2483-2490.

9. Yang S, Fujikado N, Kolodin D, Benoist C, Mathis D. Immune tolerance. Regulatory $\mathrm{T}$ cells generated early in life play a distinct role in maintaining self-tolerance. Science 2015;348:589-594.

10. Macpherson A, Smith K. Mesenteric lymph nodes at the center of immune anatomy. J Exp Med 2006;203:497-500.

11. Kunkel D, Kirchhoff D, Nishikawa S, Radbruch A, Scheffold A. Visualization of peptide presentation following oral application of antigen in normal and Peyer's patchesdeficient mice. Eur J Immunol 2003;33:1292-1301.

12. Spahn TW, Weiner HL, Rennert PD, Lügering $N$, Fontana A, Domschke W, Spahn T.W. Mesenteric lymph nodes are critical for the induction of high dose oral tolerance in the absence of Peyer's patches. Eur J Immunol 2002;32:11091113.

13. Huang FP, Platt N, Wykes M, Major JR, Powell TJ, Jenkins CD, MacPherson GG. A discrete subpopulation of dendritic cells transports apoptotic intestinal epithelial cells to $\mathrm{T}$ cell areas of mesenteric lymph nodes. $J$ Exp Med 2000;191:435-444.

14. Worbs T, Bode U, Yan S, Hoffmann MW, Hintzen G, Bernhardt G. Oral tolerance originates in the intestinal immune system and relies on antigen carriage by dendritic cells. J Exp Med 2006;203:519-527.

15. Roep B, Tree $T$. Immune modulation in humans: implications for type 1 diabetes mellitus. Nat Rev Endocrinol 2014;10:229-242.

16. Gale EA, Bingley PJ, Emmett CL, Collier T. European Nicotinamide Diabetes Intervention Trial (ENDIT): a randomised controlled trial of intervention before the onset of type 1 diabetes. Lancet 2004;363:925-31.

17. Bonifacio E, Ziegler AG, Klingensmith G, Schober E, Bingley PJ, Rottenkolber M. Effects of high-dose oral insulin 
on immune responses in children at high risk for type 1 diabetes: the Pre-POINT randomized clinical trial. JAMA. 2015;313:1541-1549.

18. Roep B. Primary prevention for type 1 diabetes mellitus? Nat. Rev. Endocrinology 2015;11:451-452.

19. Zhang ZJ, Davidson L, Eisenbarth G, Weiner HL Zhang J. Suppression of diabetes in nonobese diabetic mice by oral administration of porcine insulin. Proc Natl Acad Sci USA 1991;88:10252-10256.

20. Kamyshny A, Putilin D, Kamyshna V. Reduced deaf1 mRNA expression during STZ-induced diabetes mellitus inhibits foxp3+regulatory T-cells differentiations in rat's pancreatic lymph nodes. Mediterranean J of Biosciences 2015; (1):20-26.
Submit your next manuscript to the JICM and take full advantage of:

- Convenient online submission,

- Thorough peer review, Fast Response,

- No charges,

- Immediate publication on acceptance,

- Inclusion in Scopemed and High quality indexes,

- Research which is freely available for redistribution of the worldwide literature

To submit your manuscript, click on $h t t p: / / w w w . j i a c m . c o m$

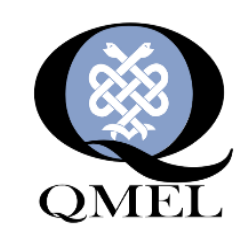

Medicine \& Publishing

Published by The ${ }^{\circledR}$ QMEL.org

Medicine \& Education \& Library

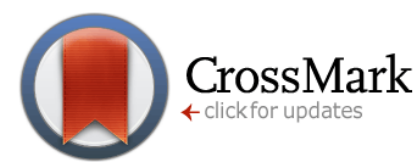

